\title{
The paired-like homeo box gene MHox is required for early events of skeletogenesis in multiple lineages
}

\author{
James F. Martin, Allan Bradley, ${ }^{1}$ and Eric N. Olson ${ }^{2}$ \\ Department of Biochemistry and Molecular Biology, The University of Texas M.D. Anderson Cancer Center, Houston, \\ Texas 77030 USA; $^{1}$ Department of Molecular and Human Genetics and Howard Hughes Medical Institute, Baylor College of \\ Medicine, Houston, Texas 77030 USA
}

Formation of cartilage and bone involves sequential processes in which undifferentiated mesenchyme aggregates into primordial condensations that subsequently grow and differentiate, eventually forming the adult skeleton. Although much has been learned about the structural molecules that compose cartilage and bone, little is known about the nuclear factors that regulate chondrogenesis and osteogenesis. MHox is a homeo box-containing gene that is expressed in the mesenchyme of facial, limb, and vertebral skeletal precursors during mouse embryogenesis. MHox expression has been shown to require epithelial-derived signals, suggesting that $M H o x$ may regulate the epithelial-mesenchymal interactions required for skeletal organogenesis. To determine the functions of $M H O x$, we generated a loss-of-function mutation in the MHox gene. Mice homozygous for a mutant MHox allele die soon after birth and exhibit defects of skeletogenesis, involving the loss or malformation of craniofacial, limb, and vertebral skeletal structures. The affected skeletal elements are derived from the cranial neural crest, as well as somitic and lateral mesoderm. Analysis of the mutant phenotype during ontogeny demonstrated a defect in the formation and growth of chondrogenic and osteogenic precursors. These findings provide evidence that MHox regulates the formation of preskeletal condensations from undifferentiated mesenchyme.

[Key Words: MHox gene; homeo box; mouse embryogenesis; skeletal organogenesis; epithelial-mesenchymal interactions]

Received March 7, 1995; revised version accepted April 10, 1995.

The vertebrate skeleton is composed of cartilage and bone, which are derived from three separate embryologic origins. The craniofacial skeleton forms primarily from cranial neural crest, the axial skeleton from somitic mesoderm, and the appendicular skeleton from lateral mesoderm (Erlbacher et al. 1995). During skeletogenesis, mesenchyme aggregates into condensations; subsequent growth and differentiation of the cells within those condensations results in the generation of mature bone or cartilage.

The central role of secondary induction in the formation of the vertebrate skull has been firmly established using tissue recombination assays. For example, blastemal cells, which give rise to facial cartilage, differentiate only if they receive an epithelial-derived signal as they migrate (Langille 1994). In the developing limb, communication between the apical ectodermal ridge (AER) and the mesodermal progress zone is required for the outgrowth of the limb skeleton (Morgan and Tabin 1994). Signals from the AER maintain the mesenchyme of the

\footnotetext{
${ }^{2}$ Corresponding author.
}

progress zone in a proliferative, undifferentiated state. As limb outgrowth occurs, mesenchymal cells emigrate from the progress zone and form the precursors of the limb skeleton. In this way specification of the limb skeleton occurs in a proximal-to-distal fashion. The influence of the AER on cells within the progress zone is essential for limb formation. If the AER is removed, limb development is arrested (Izpisúa-Belmonte and Duboule 1992). Factors such as the fibroblast growth factor (FGF), retinoic acid, and sonic hedgehog have been implicated as soluble mediators of the communication between the AER and the mesodermal progress zone (Laufer et al. 1994; Morgan and Tabin 1994; Niswander et al. 1994). The axial skeleton is derived from the sclerotomal cells within the somite and is also dependent on intercellular signaling events for its formation. Implantation of an ectopic notochord induces sclerotome and inhibits dermomyotome formation within the somite. Sonic hedgehog, which is expressed in notochord and floorplate of the neural tube, is a component of this notochord-derived signal (Fan and Tessier-Lavigne 1994; Johnson et al. 1994).

Although much has been learned about the soluble factors involved in epithelial-mesenchymal interac- 
tions, little is known about the nuclear factors that regulate these events. Homeo box-containing genes such as the $m s h$-like genes $m s x-1$ and $m s x-2$ have been implicated as regulators of inductive events in the vertebrate limb and cranium (Davidson et al. 1991; Robert et al. 1991; Takahashi et al. 1991; Satokata and Maas 1994). In addition to the $m s x$ genes, the homeo box-containing gene $M H o x$ is expressed in the limb and facial primordia during embryogenesis (Cserjesi et al. 1992; Kuratani et al. 1994).

MHox was originally identified as a nuclear factor that bound an essential element in the muscle creatine $k i$ nase enhancer (Cserjesi et al. 1992). It was also isolated independently using a polymerase chain reaction (PCR)based strategy (Kern et al. 1992). The human homolog of MHox, called Phox, was cloned in a yeast screen for proteins that interact with serum response factor (SRF) to activate transcription through the serum response element (Grueneberg et al. 1992). Within the homeo domain, MHox is most closely related to the paired family of homeo box-containing genes. However, MHox lacks a Paired domain and contains a glutamine in place of serine at position 9 of the recognition helix that determines DNA-binding specificity of the homeo domain (Desplan et al. 1988). During mouse and chick embryogenesis, MHox is expressed in the lateral mesoderm and in the mesenchyme of the limb buds and facial primordia, but its expression is excluded from overlying epithelial tissues. Removal of surface epithelium inhibits expression of $M H O x$ in the underlying mesenchyme, suggesting that $M H O x$ may respond to or mediate inductive signals emanating from the epithelium (Kuratani et al. 1994).

To investigate the role of MHox in mouse embryogenesis, we generated mice carrying a germ-line mutation in the $M H o x$ locus. The MHox mutant mice died neonatally and displayed multiple craniofacial defects resulting from the deletion or malformation of specific skeletal elements derived from the neural crest of the first branchial arch and cephalic mesoderm. In addition, MHox mutant mice had a limb defect in which the mutant zeugopod was bowed and foreshortened. However, proximal and distal limb structures were spared. A small percentage of $M H o x$ mutants also exhibited abnormalities of the thoracic and lumbar spine, in which the neural arches were flared and the cartilaginous precursors of the dorsal spinous process were truncated, resulting in spina bifida. Analysis during ontogeny revealed that the skeletogenic abnormalities identified in the MHox mutant mice arose as a consequence of a defect in growth of chondrogenic and osteogenic precursors. These findings reveal that $M H o x$ plays a central regulatory role in the tissue interactions that give rise to craniofacial and limb skeletal structures and, to a lesser extent, the axial skeleton.

\section{Results}

Generation of MHox mutant mice

To introduce a mutation in the MHox gene, we constructed a targeting vector containing $6.5 \mathrm{~kb}$ of genomic DNA encompassing the region of the MHox gene that encodes the homeo domain, and the neomycin resistance cassette was inserted into the $5^{\prime}$ region of the homeo box (Fig. 1A,B). The linearized targeting vector was electroporated into AB-1 embryonic stem (ES) cells which were then subjected to positive-negative selection using G-418 and FIAU (see Materials and methods).

Insertion of neo into the MHox locus introduced novel EcoRI, NcoI, and ClaI sites that could be used to distinguish the targeted from the wild-type MHox allele by Southern analysis. From a total of 590 ES cell clones, 38 specific targeted events were identified by Southern analysis for a targeting frequency of $\sim 1: 15$. Two independent ES clones containing an $M H o x$ mutant allele were injected into 3.5-day blastocysts derived from C57Bl/6 mice, and chimeras were obtained. Transmission of the mutation through the germ line yielded offspring heterozygous for the mutant $M H o x$ allele. Subsequent heterozygous intercrosses resulted in the generation of mice homozygous for the mutant allele. Southern blot analysis of tail DNA from mice of the three $M H O x$ genotypes $(+1+,+1-$, and $-1-)$ is shown in Figure lC. Genotyping of 253 neonatal and embryonic mice revealed that the neonatal MHox mutant mice were produced at a Mendelian frequency, demonstrating that the MHox mutant mice survived throughout gestation.

To confirm that the targeted gene expressed no functional MHox transcripts, MHox mRNA from wild-type $1+1+1$ and mutant $(-1-)$ animals was analyzed by reverse transcriptase PCR (RT-PCR) using primers surrounding the region of the $M H O X$ mRNA where neo was inserted. The $M H O x$ transcript from the wild-type mouse and the 10T1/2 cell line, which expresses high levels of MHox mRNA, gave rise to an amplified product of $350 \mathrm{bp}$ (Fig. 1D). However, no PCR product was detected in the MHox mutant mice, demonstrating that the MHox mRNA was disrupted by the mutation. Transcripts for the ubiquitously expressed ribosomal protein $\mathrm{L} 7$ were analyzed as an internal control to confirm the integrity of the RNA.

The MHox $1-1-\mid$ mutation results in neonatal lethality and craniofacial abnormalities

MHox (-/ - ) mice were readily identifiable at birth because of cranial abnormalities, including microcephaly, low-set ears, and a pointed snout (Fig. 1E-H). The mutant neonates also demonstrated respiratory compromise as evidenced by gasping motions and cyanosis. Mutant mice never fed, and they developed abdominal distention due to inflation of the digestive tract with air.

Gross examination of $M H O x$ mutant neonates revealed that they had a large cleft of the secondary palate (Fig. $2 A, B)$, which may have contributed to their difficulty in feeding and breathing. Coronal sections through the head clearly showed the unfused palatal shelves in the mutants (Fig. 2C and D).

\section{Numerous cranial skeletal elements are altered or absent in MHox-mutant neonates}

To identify the specific anatomic defects underlying the craniofacial abnormalities in $\operatorname{MHox}(-/-)$ mice, skele- 


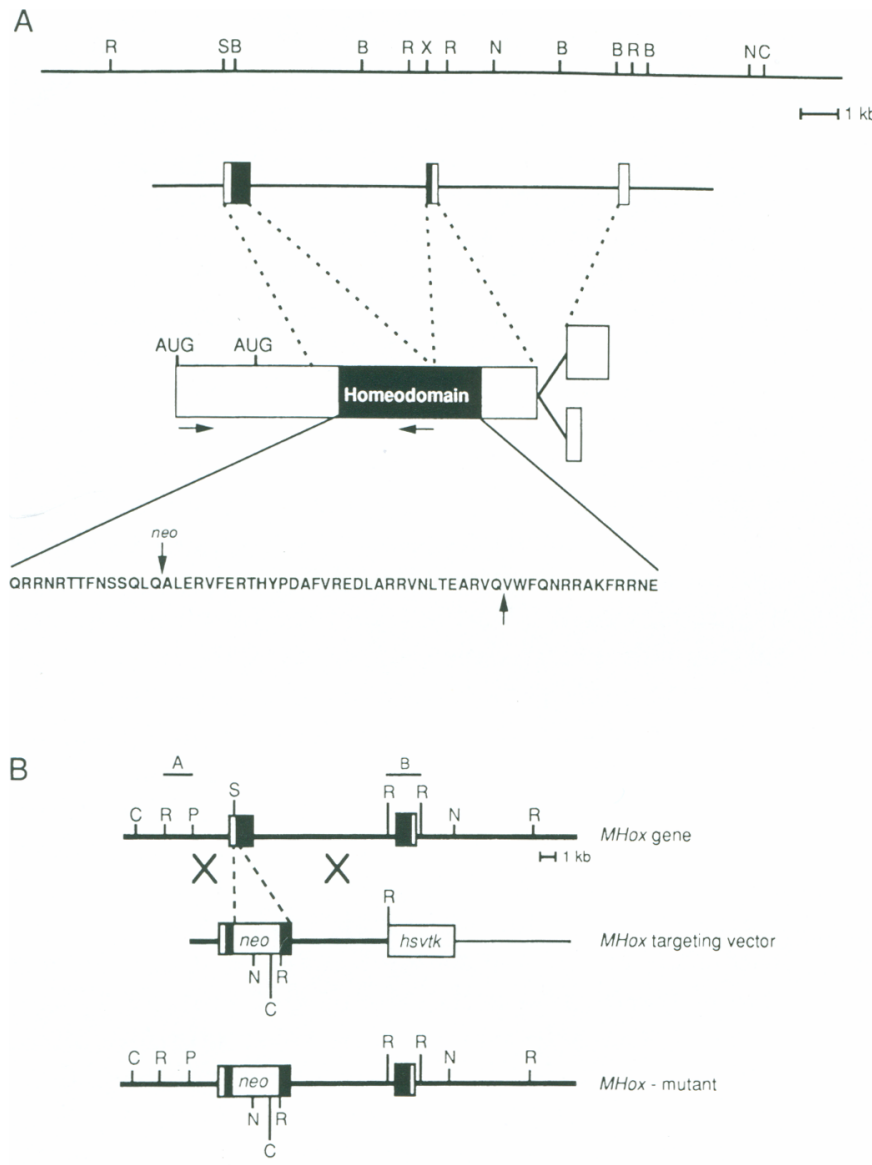

C
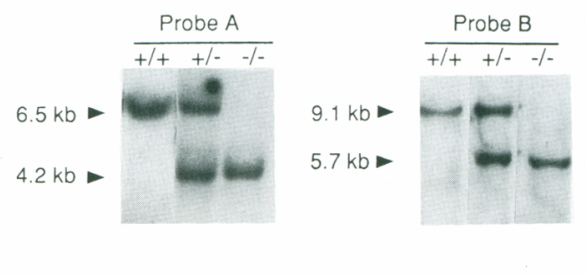

D
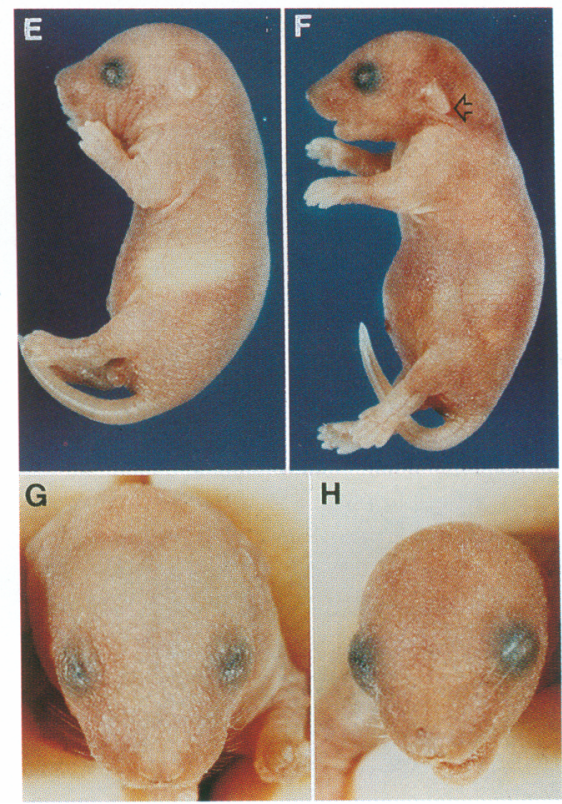

Figure 1. Targeting of the mouse MHox locus. (A) Restriction map of the region of the MHox gene encoding the homeo domain (indicated in black). The restriction sites are EcoRI $(\mathrm{R}), \operatorname{StuI} \mid \mathrm{S}), B g I \mathrm{II}(\mathrm{B}), X b a \mathrm{I} \mid \mathrm{X}), N c o \mathrm{I}(\mathrm{N})$, and $C l a \mathrm{I}(C)$. The amino acid sequence of the homeo domain is shown. The position of the intron is indicated by the vertical arrow below the sequence; the insertion site of the neo cassette is indicated by the vertical arrow above the sequence. The positions of two alternative $3^{\prime}$ exons are indicated downstream of the homeo domain (Cserjesi et al. 1992; Kern et al. 1992). Both potential AUG codons are also shown. The positions of PCR primers used for RT-PCR are indicated by horizontal arrows. (B) Strategy for targeting the MHox locus. The region of the $M H$ ox gene that was targeted is shown at the top. The targeting vector (middle), contained neo within the homeo domain at the position indicated in $A$; the predicted structure of the targeted MHox allele is shown at the bottom. The positions of the two probes used for Southern analyses are indicated at the top. $(C)$ Southern blots of genomic DNA from mice of the three MHox genotypes $\mid+1+,+1-,-1-1$ are shown. Probe A hybridizes to bands of 6.5 and $4.2 \mathrm{~kb}$ in genomic DNA from wild-type and MHox mutant mice, respectively, digested with EcoRI. Probe B hybridizes to bands of 9.1 and $5.7 \mathrm{~kb}$ in genomic DNA from wild-type and MHox mutant mice, respectively, digested with Ncol plus ClaI. (D) Transcripts for MHox and $\mathrm{L} 7$ were detected by RT-PCR as described in Materials and methods. RNA from $10 \mathrm{~T} 1 / 2$ cells was included as a positive control. No RT-PCR products were detected when reverse transcriptase was omitted from the reaction (data not shown). $(E, F)$ Lateral views of wild-type $(E)$ and $M H o x(-/-)(F)$ neonates. The arrow in $F$ denotes the low-set ear of the mutant. This mutant is also beginning to show abdominal distention and lacks milk in its stomach, which can be seen in the wild-type littermate. $(G, H)$ Frontal views of wild-type $(G)$ and $M H o x(-/-)(H)$ neonates. Note the microcephaly and pointed snout of the mutant.

tons of neonates were stained for cartilage and bone. Several major defects were readily apparent in the skulls of the mutant mice. The squamosal bone and the ascending lamina of the alisphenoid bone were absent, resulting in a large defect on the lateral aspect of the skull (Fig. 3, cf. $A, C, E$, with $B, D, F)$. There was also no trace of the zygomatic bone, gonial bone, tympanic ring (Fig. 3B,D,F), or supraoccipital bone (Fig. 4B). At the base of the skull, the pterygoid bone was hypoplastic and the palatal processes of the palatal and maxillary bones were missing (Fig. $2 E, F$; data not shown). Several defects were also observed in mandibles from $M H o x$ mutant mice. The coronoid, condylar, and angular processes of the mandible were hypoplastic, and the dentary component was shortened in all mutant animals (Fig. 3G,H). The alveolar processes and tooth buds, however, were unaffected. These affected skeletal structures of the MHox mutant mice are derived primarily from neural crest of the first branchial 


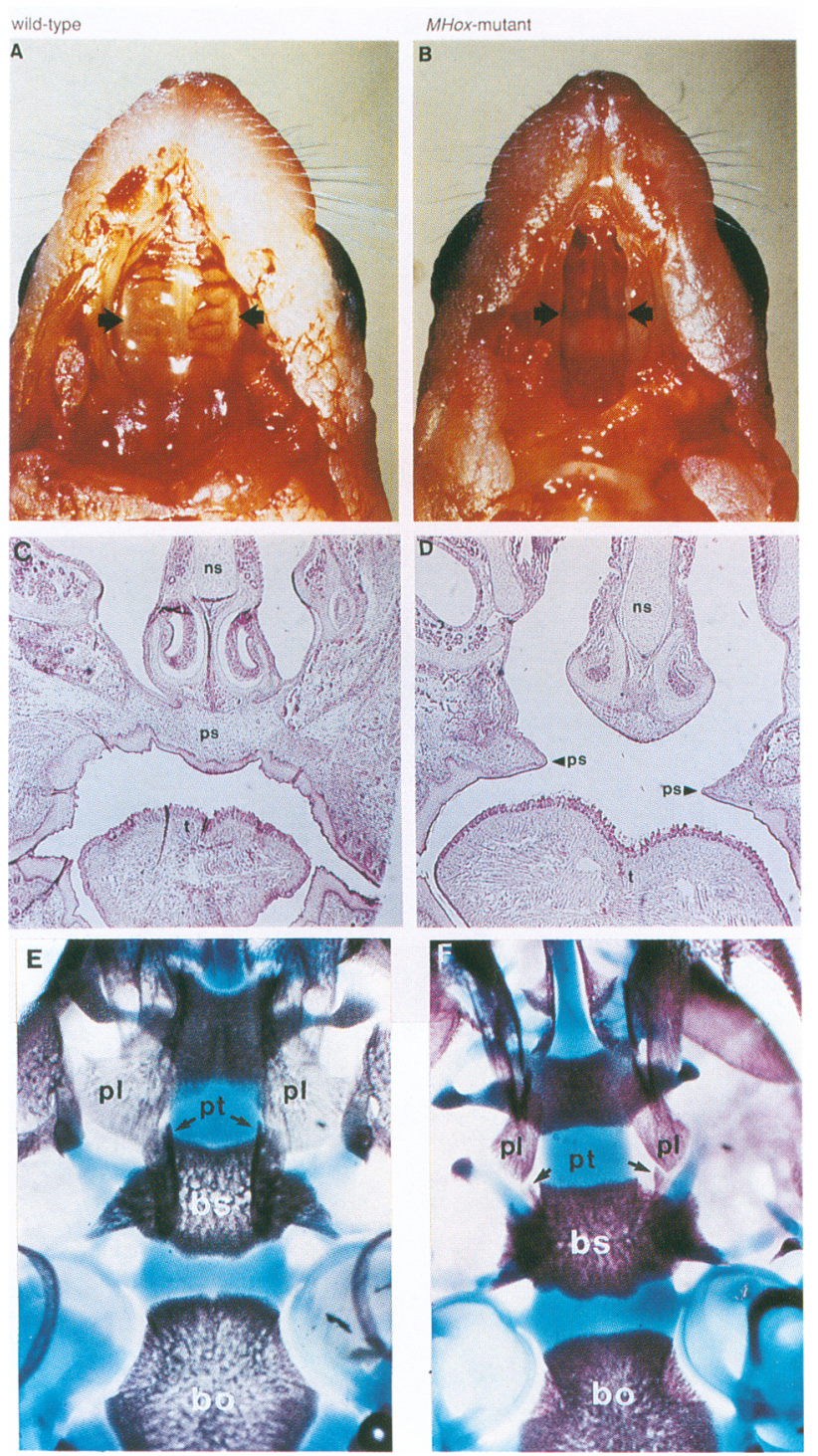

Figure 2. MHox mutant mice are born with bilateral cleft of the secondary palate. $(A, B)$ Ventral view of the upper jaw of wild-type and $M H O x(-/-)$ neonates, respectively. The arrows point to the lateral edges of the secondary palate. Note there is no outgrowth of the palatal shelves in the mutant, leaving an open view of the nasal cavities, whereas the palatal shelves have fused at the midline in the wild type. $(C, D)$ Coronal sections of the heads of wild-type and MHox(-/-) neonates, respectively, showing the palatal shelves. The palatal shelves in the mutant failed to extend toward the midline. Magnification, $108 \times .(E, F)$ Ventral view of the base of skulls of wild-type and $M H O x(-1-)$ neonates, respectively. Skulls were stained for bone (purple) and cartilage (blue). The palatal and pterygoid bones are hypoplastic in the mutant. (bo) Basioccipital bone; (bs) basisphenoid bone; (ns) nasal septum; (pl) palatal bone; (ps) palatal shelves; (pt) pterygoid bone; $(t)$ tongue.

arch, except for the alisphenoid and supraoccipital bones, which are derived from cephalic mesoderm (Noden 1988; Le Douarin et al. 1993). Both membranous bones, such as the squamosal, and enchondral bones, such as the supraoccipital, were affected by the mutation.

In addition to the cranial and jaw abnormalities, the MHox mutation resulted in several defects in the middle ear ossicles, which arise from first-and second-arch neural crest (Le Douarin et al. 1993). In modern mammals the malleus, incus, and stapes form an ossicular chain that functions to transmit sound. The head of the malleus, which is derived from the proximal end of Meckel's cartilage (Novacek 1993), was the correct size in the mutant neonates. However, the manubrium of the malleus, which normally attaches to the tympanic membrane, was truncated and the processus brevis was displaced (Fig. 5, cf. A and B). Rostral to the mallear head, an additional cartilaginous process was identified in every mutant animal examined (Fig. 5B). During development, the incus, which is derived from the proximal end of the palatoquadrate cartilage (Novacek 1993), forms a separate cartilaginous body that articulates with both the stapes and the head of the malleus. In MHox mutants, the incudo-mallear joint was intact but the incus remained fused to a persistent quadrate cartilage on the lateral aspect of the skull and so did not articulate with the stapes (Fig. 5, cf. C and D).

The third middle ear ossicle, the stapes, is derived from the rostral portion of Reichert's cartilage in the second pharyngeal arch (Moore and Persaud 1993). In mutant mice, the stapes was columelliform and remained fused to Reichert's cartilage. In addition, the anterior and posterior crus were fused, obliterating the foramen through which the stapedial artery normally passes (Fig. 5, cf. E and F).

All of the above defects were fully penetrant. The head structures that were affected by the $M H O X$-null mutation were highly specific, as many cranial bones were unaffected. Table 1 summarizes the cranial defects in $M H o x$ mutant mice, which were restricted primarily to skeletal elements derived from cranial neural crest within the first branchial arch and, to a lesser extent, to structures that arise from the second arch crest and the cephalic mesoderm. Transverse and coronal sections through the head of MHox mutant neonates revealed that the cranial musculature was intact (not shown). Because cranial neural crest cells give rise to both neurogenic and skeletogenic components of the head and face (Noden 1983 1988; Le Douarin et al. 1993|, we analyzed the trigeminal nerve, which innervates the first branchial arch and its derivatives. Histologic analysis showed that the trigeminal (Gasserian) ganglion was normal in mutant animals (not shown). Immunostaining of embryos 10.5 days postcoitum (dpc) with an anti-neurofilament antibody also showed that cranial nerves VII, IX, and X were unaffected by the MHox mutation (not shown).

\section{Developmental time course of the cranial mutant phenotype}

To begin to define which developmental processes were affected by the $M H O x$ mutation, we examined the forming cartilaginous and bony skeletons of mouse embryos. 


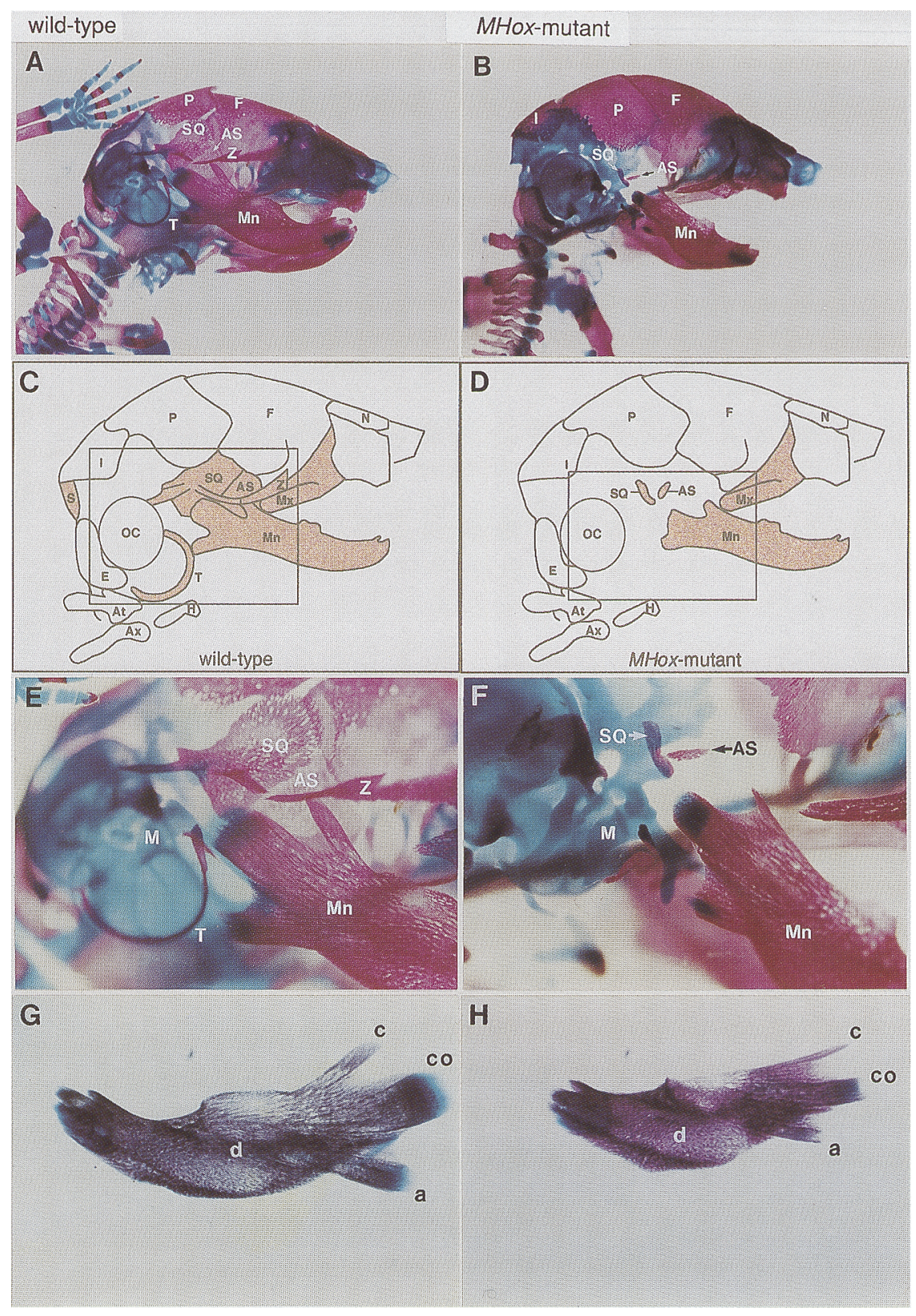

Figure 3. Lateral views of the skulls of wild-type and MHox mutant neonates. Lateral views of the skulls and upper vertebral region of wild-type $(A, C, E)$ and $M H o x(-/-)(B, D, F)$ neonates stained for bone (red) and cartilage (blue) $(C, D) \mathrm{A}$ diagram of the skull bones in wild-type and mutant neonates, respectively; $(E, F)$ an enlargement of the region indicated by the boxes in $C$ and $D$. Skeletal structures that are altered in the mutant are indicated in pink in $C$ and $D .(G, H)$ The isolated mandibles from wild-type and mutant neonates, respectively. In $F$, note that only remnants of the squamosal and alisphenoid bones appear in the mutant, resulting in the absence of a temporomandibular joint. The coronoid, condylar, and angular processes of the mandible are also hypoplastic, and the tympanic, gonial, and zygomatic bones are absent. (A), Angular process; (At) atlas; (AS) alisphenoid bone; (Ax) axis; (C) coronoid process; (CO) condylar process; (D) dentary process; $(\mathrm{E})$ exoccipital bone; $(\mathrm{F})$ frontal bone; $(\mathrm{H})$ hyoid bone; (I) interparietal bone; (M) malleus; $(\mathrm{Mn})$ mandible; $(\mathrm{Mx})$ maxillary bone; $(\mathrm{N})$ nasal bone; $(\mathrm{OC})$ otic capsule; $(\mathrm{P})$ parietal bone; (SQ) squamosal bone; (S) supraoccipital bone; $(\mathrm{T})$ tympanic bone; $(\mathrm{Z})$ zygomatic bone.
Cartilage staining of mutant and wild-type embryos demonstrated that the MHox mutant phenotype was apparent at $13.5 \mathrm{dpc}$. The defects at this stage included the absence of the tectum posteriorus, the cartilaginous precursor of the supraoccipital bone (Fig. 6A,B). Meckel's cartilage remained unfused and had a sigmoidal morphology in mutant embryos, compared with the straight rod of cartilage seen in wild-type embryos. In addition, the ala temporalis, a cartilaginous structure that gives rise to the alisphenoid bone, was detectable in wild-type embryos at this stage but was not present in mutant embryos (Fig. 6C,D). One day later, the mutant Meckel's cartilage fused, although it remained morphologically abnormal (Fig. 6E-H). The ala temporalis, though present, remained hypoplastic relative to wild type (not shown). The forming occipital arch and parietal cartilage remained deficient in the MHox mutant mice at $14.5 \mathrm{dpc}$ (Fig. 6E,F). Fusion of the incus to the persistent quadrate cartilage on the lateral aspect of the skull was also obvious at this stage. The abnormal formation of cartilage in the developing skull of the MHox mutant results in a trabeculated appearance characteristic of phylogenetically more primitive animals (Fig. 6E,F; Novacek 1993). Thus, many of the morphologic abnormalities observed in the mutant neonates were the end result of the failure of cartilaginous precursors to form or grow at normal rates. Similarly, ossification centers for the membranous squamosal and tympanic bones, which were deleted in mutant neonates, were never detected in 14.5 and 16.5 dpc mutant embryos (not shown). 
Figure 4. Deletion of the supraoccipital bone from $M H o x-$ mutant mice. Posterior views of the skulls of wild-type $(A)$ and $M H o x-$ mutant $(B)$ neonates, respectively, stained for bone (red) and cartilage (blue). The arrow in $A$ points to the supraoccipital bone, which is absent in the mutants $(B)$. (A) Atlas; (E) exoccipital bone; (I) interparietal bone; (P) parietal bone; (S) supraoccipital bone.

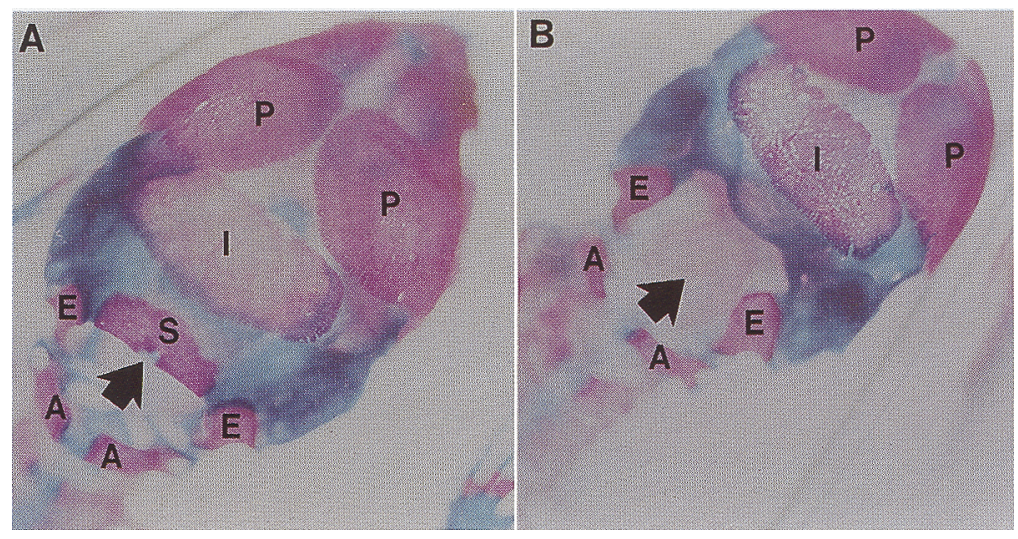

\section{Limb abnormalities in MHox mutant embryos and neonates}

During embryogenesis, $M H O x$ is expressed in the lateral mesoderm prior to limb formation and later in the mesenchyme of the forming limb bud (Cserjesi et al. 1992; Kuratani et al. 1994) In MHox mutant neonates, the ossified shafts of the radius and ulna of the forelimb and the tibia and fibula of the hindlimb were abnormally shortened and broader than wild-type bones (Table 2). In addition, the radius and tibia of mutant animals had a bowed shape when compared to wild-type structures (Fig. 7). No defects were detected in the epiphyseal cartilage of the long bones of neonatal animals by wholemount cartilage staining or by histologic analysis (Fig. 7; data not shown). The proximal and distal limb structures were unaffected (Table 2).

The long bones of the extremities form by endochondral ossification in which a cartilaginous template is replaced by bone (Ham 1987). Analysis of the cartilaginous precursors of the affected long bones at $13.5 \mathrm{dpc}$ demonstrated that they were also bowed and foreshortened (Fig. $8 \mathrm{~A}, \mathrm{~B})$. At $14.5 \mathrm{dpc}$, the long bones of the mutants revealed a delay in formation of the diaphyseal ossification center, and the bowing was more pronounced (Fig. 8CF). Thus, the abnormalities evident in the limbs of the mutant neonates can be traced to a defect in formation and subsequent ossification of specific cartilaginous precursors.

\section{Vertebral defects in MHox mutant mice}

Analysis of skeletons of $M H O x$ mutant neonates revealed that $\sim 12 \%$ of the $M H$ ox mutant mice had abnormalities of the dorsal aspects of the thoracic and lumbar vertebrae. The neural arches of the affected vertebrae were abnormally shaped (Fig. 9). In wild-type neonatal mice, the neural arches form a convex structure that surrounds the spinal cord laterally while the cartilaginous precursor of the spinous process forms the dorsal covering of the spinal cord. In MHox mutant mice, the neural arches failed to form a convex structure but were, instead, flared laterally. In addition, the dorsal cartilaginous structures were truncated. The result of these abnormalities was spina bifida.

\section{Discussion}

We have analyzed the functions of the $M H O x$ homeo box gene by gene targeting in mice. MHox mutant mice showed defects in numerous skeletal structures that are derived from the neural crest, the lateral mesoderm, and the somitic mesoderm. The observed defects can be classified primarily as deletion or hypoplasia of specific elements that can be traced to absent and growth-retarded precursors. The MHox mutation affected both endochondral and membranous bones, which form by distinct pathways. In the case of endochondral bone, mesenchyme condenses into cartilage, which in turn grows and differentiates and is eventually replaced by bone. The formation of membranous bone is not preceded by a cartilaginous intermediate; rather, mesenchymal condensations directly give rise to osteoblasts (Ham 1987).

\section{The MHox mutation results in abnormalities of a subset of cranial structures}

The effects of the MHox mutation are especially dramatic in the skull, where multiple bones were deleted or malformed. Table 1 gives a summary of the cranial defects in MHox mutant mice, which were restricted to skeletal elements derived from cranial neural crest within the first branchial arch and, to a lesser extent, to structures that arise from the second arch neural crest and the cephalic mesoderm. Skeletal elements derived from the first branchial arch were affected most severely by the MHox mutation (Table 1). Many first arch derivatives, including the tympanic, palatine, squamosal, pterygoid, and zygomatic bones, were ablated or hypoplastic in MHOX mutant neonates. The malleus and incus, which are also derived from the first arch, both showed ectopic cartilaginous processes and severe malformations. The maxilla and mandible were also hypoplastic in MHox mutant mice but were not affected as severely as other first arch derivatives. The only second 



Figure 5. Abnormalities of the middle ear of $M H O x(-/-\mid$ mice. Lateral views of the dissected middle ear ossicles of wild-type $(A, C, E)$ and $M H o x(-/-)(B, D, F)$ mice. $(A, B)$ Malleus; $(C, D)$ incus; and $(E, F)$ stapes; $(G, H)$ Diagrams of the malleus-incus-stapes complexes as they appear in the skulls of wild-type and mutant neonates, respectively. Note the complete absence of the tympanic and gonial bones in the mutant $(B)$. The manubrium of the malleus in the $M H o x$ mutant is truncated, and the processus brevis is posteriorly displaced $(A, B)$. The arrows in $B$ and $H$ point to an ectopic process of Meckel's cartilage. The incus from the mutant $(D)$ is fused to a persistent quadrate cartilage on the lateral aspect of the skull. The wild-type stapes is stirrup-shaped $(E)$ while the mutant stapes is columelliform $(F)$. (c) Crus of the stapes; $(E)$ exoccipital bone; $(F)$ frontal bone; (fp) foot plate of the stapes; $(G)$ gonial bone; $(I)$ incus; $(\mathrm{LH})$ lesser horn of the hyoid; (lp) long process of the incus; $(\mathrm{M})$ malleus; $(\mathrm{mb})$ manubrium of the malleus; $(\mathrm{mc}) \mathrm{Meckel}$ 's cartilage; $(\mathrm{pb})$ processus brevis of the malleus; (rc) Reichert's cartilage; (S) stapes; (SO) supraoccipital bone; (St) styloid bone; (SL) stylohyoid ligament; (T) tympanic bone.

arch structure to be affected by the MHox mutation was the stapes, a derivative of Reichert's cartilage.

Most knowledge of the embryonic origins of the vertebrate skull is extrapolated from chick-quail grafting experiments. These studies have shown that the cranial and visceral arch skeletons are derived from the cranial neural crest, the cephalic mesoderm, or the occipital somites (Noden 1988; Lumsden et al. 1991; Le Douarin et al. 1993). Neural crest cells that contribute to the first and second arches originate from the dorsal neural tube at the level of rhombomeres $1-4$ and undergo an epithelial-to-mesenchymal transition as they migrate (Lums- den et al. 1991; Sechrist et al. 1993|. Migration of cranial neural crest cells occurs in two waves: the first wave gives rise to cartilage, bone, and connective tissues, and the second to neurogenic derivatives (Nichols 1986). The affected neural crest-derived bones of the skull, such as the squamosal and zygomatic bones, form by membranous ossification. Ossification centers for these bones were never detected in MHox mutant mice during embryogenesis, suggesting that the formation of the precursors of these bones had been perturbed. The abnormalities detected in endochondral bone of the skull of mutant mice can be related to defects in formation of 
Table 1. Defects in skeletal structures derived from the pharyngeal arches in MHox mutant mice

\begin{tabular}{ll}
\hline Derivatives & Defect \\
\hline $\begin{array}{l}\text { First arch } \\
\text { Meckel's cartilage } \\
\text { malleus } \\
\text { incus }\end{array}$ & $\begin{array}{l}\text { ectopic process } \\
\text { truncated manubrium } \\
\text { fused to cartilaginous mass } \\
\text { in lateral skull } \\
\text { tympanic bone }\end{array}$ \\
maxillary bone & missing palatal process \\
dentary (mandibular) bone & hypoplastic angular, \\
& coronoid process and head \\
& of ramus \\
palatine bone & remnant \\
squamosal bone & remnant \\
pterygoid bone & remnant \\
zygomatic bone & absent \\
Second arch & fusion of anterior and \\
stapes & posterior crus; fusion to \\
& Reichert's cartilage \\
\hline
\end{tabular}

cartilaginous precursors. For example, the precursors of the supraoccipital and alisphenoid bones were either missing or growth delayed.

The absence of skeletal elements of MHox mutants was not likely a result of a defect in neural crest cell migration or specification because $M H O x$ expression is first detected after the onset of these events (Cseriesi et al. 1992). Moreover, expression of the neural crest marker AP2 (Mitchell et al. 1991) in the first branchial arch was normal in $M H o x$ mutant embryos (not shown). The $M H O X$ mutation also produced no detectable effect on the cranial ganglia, which form from neurogenic neural crest cells in the first and second arch (not shown). These findings suggest that only a subset of the mesenchymal neural crest require $M H O x$ to complete their developmental program.

The neural crest populates the branchial arches and developing facial processes and subsequently gives rise to cartilage and bone anlagen by aggregation of loose mesenchyme. These condensations differentiate into the specific cartilage and bone of the skull. The ultimate differentiation of cranial skeletal precursors has been shown to require epithelial-mesenchymal interactions (Hall and Miyake 1992). Previous work suggesting that $M H o x$ expression in embryonic mesenchyme requires a signal from the overlying epithelium implies that $M H O x$ function is important in epithelial-mesenchymal interactions that eventually result in the differentiation of mature cartilage and bone (Kuratani et al. 1994). Interruption of these intercellular signaling pathways could account for the loss of the cranial bones observed in MHox mutant neonates.

The MHox mutation results in defects in a subset of long bones and vertebrae

During the development of endochondral long bones, chondrocytes within the diaphysis, or shaft, of a cartilage body proliferate and increase the length of the structure. These chondrocytes then mature and calcify and eventually are replaced by bone forming the diaphyseal ossification center. Late in development and postnatally, long bones lengthen as a result of growth in the cartilage of the epiphyseal growth plate. In addition, osteoblasts located within the periosteum encasing the bone lay down matrix and increase the width of the bone by appositional growth (Ham 1987). In MHox mutant neonates, the affected endochondral long bones were shorter and thicker than normal. A defect was observed in the cartilaginous templates of these long bones and later in the diaphyseal ossification center. However, the epiphyseal growth plates were unaffected by the MHox mutation. Appositional growth also seemed to be intact because the width of the bone was not diminished.

Vertebral abnormalities were also detected in a small percentage of $M H O x-$ mutant neonatal mice. Although this defect was not analyzed during ontogeny, MHox expression has been detected within the condensing vertebrae of developing mice (Cserjesi et al. 1992), suggesting that MHox plays a role in the formation of vertebral precursors. These results suggest that the endochondral bone abnormalities observed in $M H O x$ mutant mice are secondary to a defect in chondrogenesis of cartilaginous precursors.

Although the developmental processes that give rise to endochondral and membranous bone are distinct in many ways, the formation of both bone types is initiated by the aggregation of mesenchyme into prechrondrogenic and preosteogenic condensations. This critical stage of skeletogenesis precedes the overt differentiation of cartilage and bone and is dependent on epithelialmesenchymal tissue interactions for its completion (Hall and Miyake 1992). Because the MHox mutation affects both bone types, derived from all three embryologic sources, it is likely that the function of MHox is exerted at the condensation stage of skeletal development. The primary mechanisms directing formation of condensations are cell proliferation and adhesion, which result in increased local cell density. Analysis of $M H O x$ mutant embryos for abnormalities of growth rates within condensations by BrdU labeling has not revealed differences from wild-type embryos (J. Martin, unpubl.). However, it is possible that these experiments would not reveal subtle proliferative changes within the mutant condensations. Aberrations in the adhesive properties of cells within condensing mesenchyme is also a conceivable mechanism responsible for defects of condensations within MHox mutant mice. In this regard, it is interesting to note that the promoter of the cell adhesion molecule, NCAM, has a required recognition element that has been shown to bind a related factor, Phox 2 (Valarché et al. 1993).

Only a subset of embryonic structures derived

from MHox-expressing cells are affected

by the MHox mutation

During mouse embryogenesis, MHox is expressed in mesenchymal cells within the branchial arches begin- 


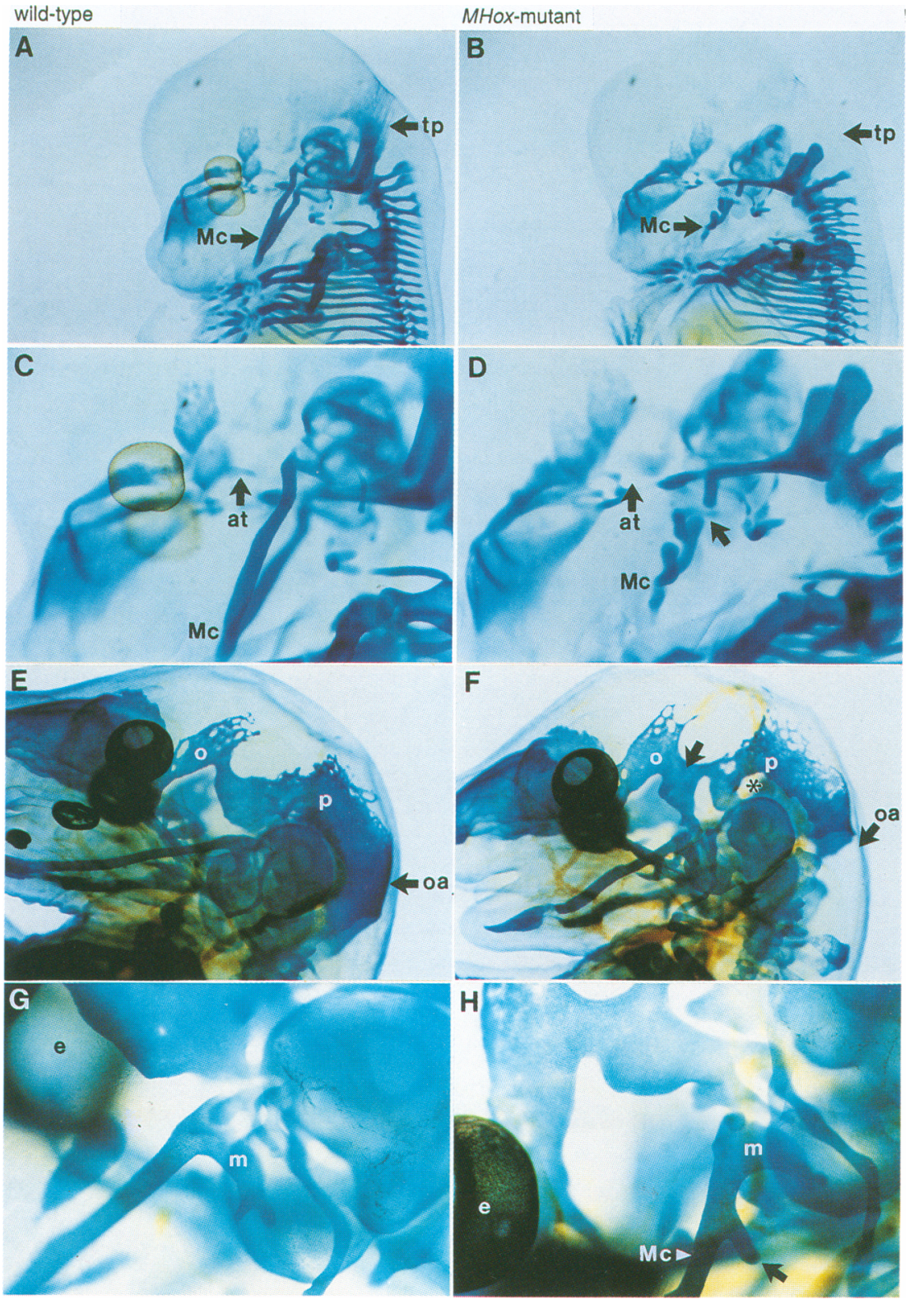

Figure 6. Whole-mount cartilage staining of wild-type and MHox mutant embryos. Lateral views of wild-type $(A, C, E, G)$ and $M H o x$ mutant $(B, D, F, H)$ embryos at 13.5 dpc $(A-D)$ and $14.5 \mathrm{dpc}(E-H)$ stained for cartilage. The cartilaginous precursor of the supraoccipital bone, the tectum posteriorus, is absent in the mutant skull. The higher magnification view in $C$ and $D$ shows that the malleus is unfused and has a sigmoidal morphology when compared to the wild type. The ala temporalis is readily identifiable in the wild type, but is absent at this stage in the mutant skull. $(E, F)$ At 14.5 $\mathrm{dpc}$ the MHox mutant has deficiencies in the parietal cartilage, (asterisk) and the developing occipital arch. The persistent quadrate cartilage that remains fused to the incus is also evident and is denoted by the arrow. $(G, H)$ A higher magnification of the malleus at $14.5 \mathrm{dpc}$ reveals the ectopic process, denoted by the arrow. (at) Ala temporalis; (e) eye; $(\mathrm{m})$ malleus; (Mc) Meckel's cartilage; $(\mathrm{tp})$ tectum posteriorus; $(\mathrm{o})$ optic cartilage; $(p)$ parietal cartilage; (oa) occipital arch. ning at about day 8.5 p.c. (Cserjesi et al. 1992; see also Kuratani et al. 1994). Subsequently, MHox expression is observed at high levels in the limb buds, lateral mesoderm, the maxillary processes, the frontonasal mass, and the prevertebrae. Not all regions of MHox expression

Table 2. Lengths of long bones

\begin{tabular}{lccc}
\hline & Wild type & $\begin{array}{c}\text { MHox } \\
\text { mutant }\end{array}$ & \\
\hline Radius & $3.9 \pm 0.1$ & $2.8 \pm 0.3$ & $P<0.001$ \\
Ulna & $4.8 \pm 0.2$ & $3.6 \pm 0.3$ & $P<0.001$ \\
Humerus & $4.3 \pm 0.2$ & $4.2 \pm 0.3$ & N.S. \\
Tibia & $4.7 \pm 0.2$ & $3.7 \pm 0.3$ & $P<0.001$ \\
Femur & $4.1 \pm 0.1$ & $4.0 \pm 0.1$ & N.S. \\
\hline
\end{tabular}

Values are expressed in millimeters \pm S.D. Significance between groups was determined using the Student's $t$-test. show defects of equal severity. In the limb buds, for example, where $M H O x$ is expressed at high levels, we detected only subtle defects in $M H O x$ mutant mice. The dichotomy of observed phenotypes between the head and limb in MHox mutant mice suggests that there may be other genes that can substitute for $M H o x$ functions within the limb. The homeodomain protein S8 would be most likely to substitute for $M H o x$ because these two homeo domain proteins are highly related within their homeo domains, bind the same DNA target sequence, and show overlapping expression patterns during mouse embryogenesis (Opstelten et al. 1991; Cserjesi et al. 1992, 1994).

Relationship of the MHox mutant phenotype to other homeo box gene mutations

The phenotype of MHox mutant mice is similar to, but distinct from those mice bearing mutations in other ho- 


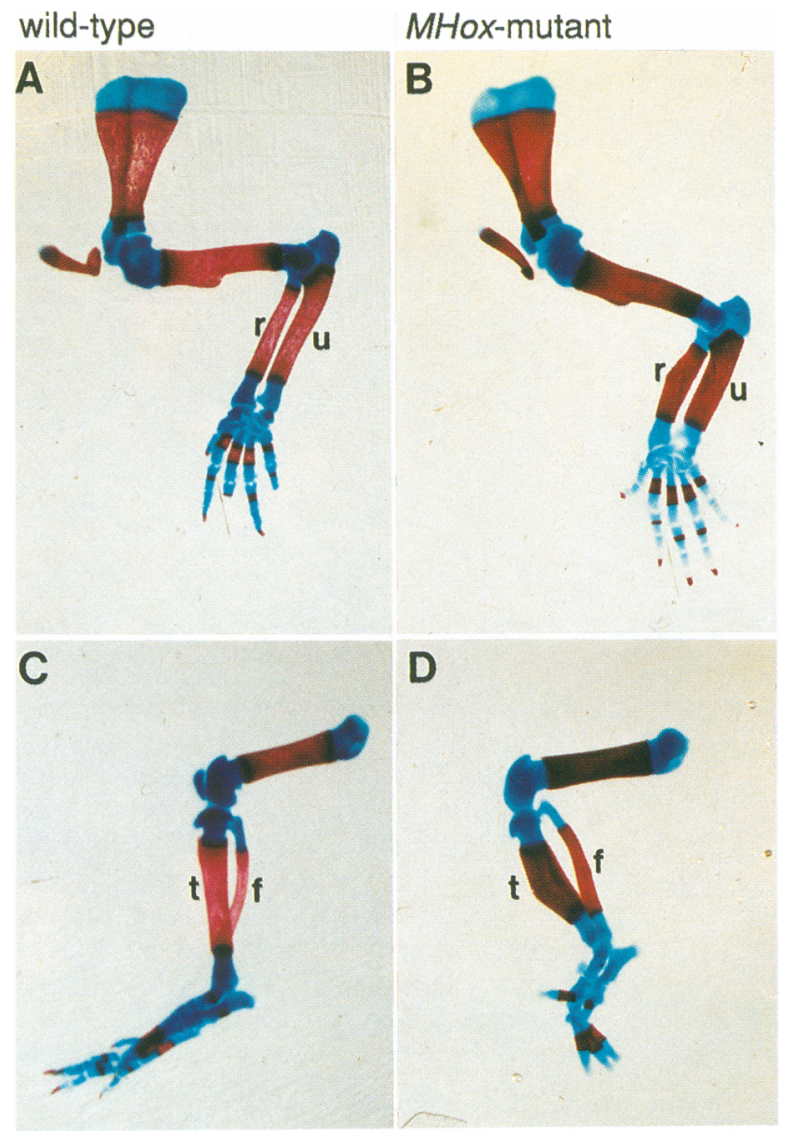

Figure 7. Limb skcleton of wild-type and MHOX mutant neonates. Bones from the forelimb $|A, B|$ and hindlimb $(C, D)$ of wild type $(A, C)$ and $M H O x$ mutant $(B, D)$ neonates were stained for bone (red) and cartilage (blue). The radius, ulna, tibia, and fibula are truncated in the mutants, whereas the humerus, femur, and distal elements are normal. (f) Fibula; $(\mathrm{r}\rangle$ radius; $(\mathrm{t})$ tibia; $(\mathrm{u})$ ulna.

meo box genes. Inactivation of the Hoxd11 and Hoxa11 genes result in limb defects involving fusions and malformations of the most distal aspects of the radius and ulna, as well as abnormalities within the autopods (Small and Potter 1993; Davis and Capecchi 1994; Favier et al. 1995|. Inactivation of the Hoxd13 gene resulted in abnormalities in autopod structures. These abnormalities can be traced to defects in the timing of formation of cartilaginous precursors (Dollé et al. 1993). Aberrant craniofacial skeletogenesis has been observed in Hoxa2 mutant mice, in which the second-arch neural crest has been respecified to a first-arch identity. These mice show duplications in some of the first-arch derived structures that are deleted in MHox mutant mice (Gendron-Maguire et al. 1993; Rijli et al. 1993). Inactivation of the $m s x-1$ gene results in abnormalities in the alveolar portion of the mandible, the malleus, and bones of the calvarium. Most of the defects in the msx-1 mutant mouse are distinct from the MHox phenotype. For example, the alveolar portion of the mandible is normal in $M H o x$ mice, and the cranial bones affected by the msx-1 muta- tion are normal in the MHox mutant. However, the mallear defect is similar to that seen in the MHox mouse, suggesting that these two genes may regulate partially overlapping developmental pathways (Satokata and Maas 1994).

\section{Atavistic changes resulting from the MHox mutation}

In modern mammals, the palatoquadrate cartilage gives rise to the incus, ala temporalis, antorbital cartilage, and the pterygoid cartilage (Novacek 1993). In MHox mutants, the incus fails to demarcate and the palatoquadrate is partially retained, forming an articulation with the malleus. Thus, the MHox mutation results in cranial skeletal components that are morphologically similar to those seen in phylogenetically more primitive animals such as reptiles.

Little is known about the molecular mechanisms regulating the development of the skull. A priori, it would be expected that insight into these mechanisms should also contribute to an understanding of how cranial diversity between taxa is generated. Embryology and studies in comparative anatomy have suggested that a common mechanism to create cranial diversity is heterochronyvariation in the timing of developmental events. For example, the emergence of snakes from reptilian ancestors is thought to have occurred by modification in the timing of formation of cranial precursors, eventually altering the morphology of the adult skull (Rieppel 1993). The MHox mutation appears to result in a cranial atavism secondary to altered growth rates of cartilaginous precursors, supporting the notion that heterochronic change is an important evolutionary mechanism used to create diversity in the vertebrate skull. Similar notions have been postulated recently to explain the phenotype observed in Hoxa 2 and Hoxd13 mutant mice. Hoxd13 mutant mice demonstrate altered growth rates of cartilage precursors in the limb, which lead to atavistic and neotenic changes in morphology (Dollé et al. 1993). In Hoxa2-mutant mice, a similar persistence of the palatoquadrate cartilage was identified (Rijli et al. 1993). The MHox mutation provides further experimental support for these ideas and so provides insight into the mechanisms that control ontogeny and evolution of the skull.

\section{Materials and methods \\ Construction of MHox targeting vector}

MHox genomic clones were isolated by screening a mouse $129 /$ Sv genomic library with the full-length $M H o x$ cDNA (Cserjesi et al. 1992). Positive clones were purified and subcloned into the pBSK2 plasmid (Stratagene). To construct the MHox targeting vector, a neomycin resistance cassette under control of the phosphoglycerol kinase (PGK) promoter was inserted into a unique Stul site near the amino terminal region of the homeo domain. A pMCl-HSV thymidine kinase gene (Mansour et al. 1988 ) was placed into a XhoI site at the $3^{\prime}$ end of the vector. Prior to electroporation, the MHox targeting vector was linearized with NotI. 


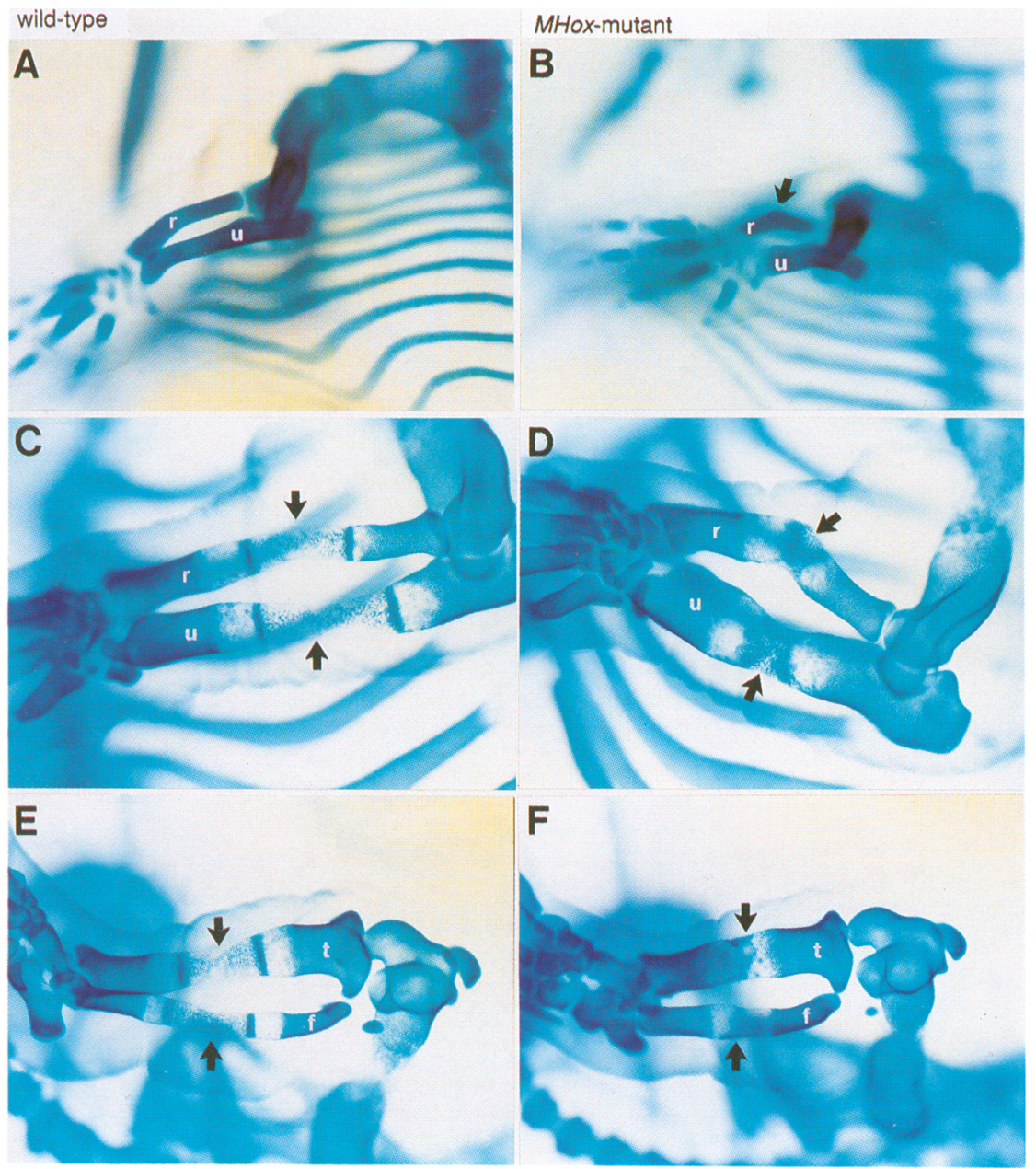

Figure 8. Limb skeleton of wild-type and $M H o x$ mutant embryos. Whole-mount cartilage staining of wild-type $(A, C, E)$ and mutant $(B, D, F)$ embryos at $13.5 \mathrm{dpc}(A, B)$ and $14.5 \mathrm{dpc}(C-F)$. At $13.5 \mathrm{dpc}$ the cartilaginous precursors for the radius and ulna of the upper limb are bowed and shorter than normal $(A, B)$. At $14.5 \mathrm{dpc}$ the defect in the radius and ulna of the upper limb $(D)$ and the tibia and fibula of the hindlimb $(F)$ are more apparent. The arrow in $B$ points to the misshapen radial precursor. The arrows in $C-F$ point to the diaphyseal ossification center, which is delayed in the mutant limb. (f) Fibula; (r) radius; (t) tibia; (u) ulna.

\section{Generation of MHox-null mice}

The MHox targeting vector $(50 \mu \mathrm{g})$ was electroporated into $A B-1$ ES cells (McMahon and Bradley 1990) using a Bio-Rad gene pulser $(500 \mu \mathrm{F}, 240 \mathrm{~V})$, and cells were plated on SNL76/7 cells and cultured under the positive and negative selection of G-418 and FIAU (McMahon and Bradley 1990). Addition of FIAU to the medium resulted in an approximate eight-fold enrichment for targeting events. Following selection, surviving clones were isolated and replica plated onto SNL 76/7 fibroblast feeder cells in 96-well plates. Southern analysis was performed on these colonies as described (Ramirez-Solis et al. 1992) using an EcoRI digest and probe A (see Fig. 1A). Ten ES cell clones that were found to contain targeted events within a single MHox allele were expanded, and their genomic DNA was analyzed further by Southern analysis using multiple restriction enzymes to confirm the targeting events. Rearrangements in the vicinity of the MHox locus were not detected. Two independent clones were injected into $3.5 \mathrm{dpc}$ mouse embryos that were reimplanted into foster mothers to generate high percentage chimeras. One chimera transmitted the mutation through the germ line, giving rise to mice heterozygous for the MHox mutation.

\section{Genotyping of progeny}

To identify mice carrying the MHox mutation, Southern blot analysis was performed on genomic DNA that was obtained from tail biopsies of neonatal and 10-day-old mice and from the yolk sacs of mouse embryos. To isolate genomic DNA, tissue was incubated in lysis buffer $10 \mathrm{~mm}$ Tris at $\mathrm{pH} 8.0,25 \mathrm{~mm}$ EDTA at $\mathrm{pH} 8.0,100 \mathrm{~mm} \mathrm{NaCl}, 1 \%$ SDS, $0.2 \mathrm{mg} / \mathrm{ml}$ of proteinase $\mathrm{K}$ ) at $50^{\circ} \mathrm{C}$ for $3 \mathrm{hr}$, followed by phenol-chloroform extraction and ethanol precipitation. Genomic DNA was digested with the indicated restriction enzyme and fractionated on a $0.7 \%$ agarose gel. Digested DNA was transferred to Zeta-probe GT membranes and hybridized with probe $A$ or $B$.

\section{RT-PCR analysis of MHox $m R N A$}

Total RNA was isolated from neonatal mice as described previously (Chomczynski and Sacchi 1987). To synthesize cDNA, $1 \mu \mathrm{g}$ of total RNA was denatured in the presence of random hexamers, followed by incubation with reverse transcriptase (BRL) at $42^{\circ} \mathrm{C}$ for $1 \mathrm{hr}$. One-fifth of the cDNA reaction mixture was used for the PCR reaction, which was performed under the following conditions: Denature at $94^{\circ} \mathrm{C}$ for $3 \mathrm{~min}, 1$ cycle; $94^{\circ} \mathrm{C}$ for 30 seconds, $60^{\circ} \mathrm{C}$ for 30 seconds, $72^{\circ} \mathrm{C}$ for $1 \mathrm{~min}, 28$ cycles; $72^{\circ} \mathrm{C}$ for 15 min, 1 cycle. Each PCR reaction mixture contained $0.5 \mu \mathrm{Ci}$ of $\left[{ }^{32} \mathrm{P}\right] \mathrm{dCTP}$ for detection of the amplified products. The sequence of L7 oligonucleotides has been described (Hollenberg et al. 1993). The sequence of the oligo nucleotides used for amplifying the MHox transcript were as follows: $\mathrm{MH}-\mathrm{B}$, $5^{\prime}$-ACC ATG ACC TCC AGC TAC GG-3' and MH-O, 5' -TCC 


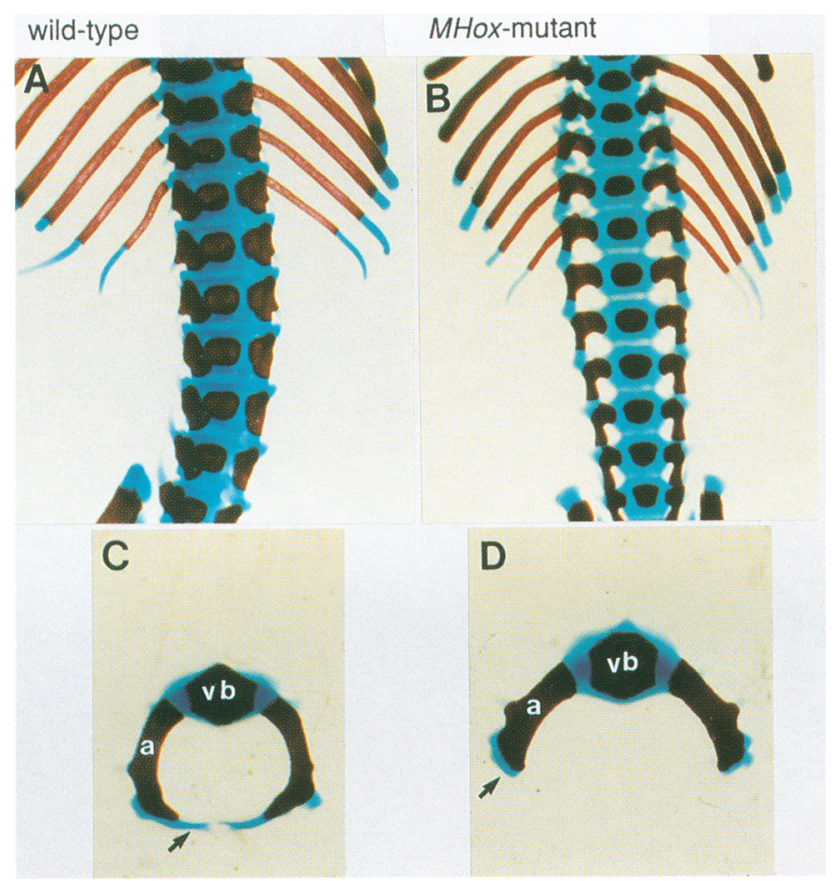

Figure 9. Vertebral abnormalities in $M H o x$ mutant animals. The vertebral skeletons from wild-type $(A, C)$ and mutant $(B, D)$ neonates were stained for cartilage and bone. The lower thoracic and lumbar spine of the mutant was abnormally widened $(B)$. Dissected first lumbar vertebrac from wild type $(C)$ and mutant $(D)$ are representative of the defect in which the vertebral arch is abnormally flared and the dorsal cartilage is truncated. (a) Vertebral arch; $(\mathrm{vb})$ vertebral body. The arrows denote the dorsal cartilage that is truncated in the mutant.

GCT CAA AGA CAC GCT CC-3'. After amplification, onetenth of the reaction mixture was fractionated on a $6 \%$ acrylamide gel.

\section{Skeletal analysis}

Neonatal mice were eviscerated and placed in water overnight. Skeletons were immersed in a $65^{\circ} \mathrm{C}$ water bath for $1 \mathrm{~min}$, skinned, and fixed in $100 \%$ ethanol for 3 days followed by alcian blue stain (15 mg of alcian blue $8 \mathrm{Gx}$ (Sigma), $80 \mathrm{ml}$ of $95 \%$ ethanol, $20 \mathrm{ml}$ of glacial acetic acid) for 8-12 hr. Skeletons were rinsed in $100 \%$ ethanol overnight and cleared in $2 \% \mathrm{KOH}$ for 6 hr. Counterstaining for bone was performed using alizarin Red (Sigma, $50 \mathrm{mg} /$ liter of $2 \% \mathrm{KOH}$ ) for $3 \mathrm{hr}$. Skeletons were cleared in $2 \% \mathrm{KOH}$ and stored in $100 \%$ glycerol.

\section{Histology}

Embryos and neonates were fixed in Bouin's solution or $4 \%$ paraformaldehyde overnight and then dehydrated through graded alcohols and embedded in paraffin. Paraffin blocks were sectioned at $7-10 \mu \mathrm{m}$ and stained with hematoxylin and eosin.

\section{Acknowledgments}

We are grateful to Peter Cseriesi for providing a MHox genomic clone, to A. Tizenor for assistance with graphics, to K. Tucker for editorial assistance, and to Richard Behringer for comments on the manuscript. This work was supported by grants from the National Institutes of Health (NIH) and The Robert A. Welch Foundation to E.N.O. and from the Howard Hughes Medical Institute to A.B. J.F.M. was supported by an NIH training grant.

The publication costs of this article were defrayed in part by payment of page charges. This article must therefore be hereby marked "advertisement" in accordance with 18 USC section 1734 solely to indicate this fact.

\section{References}

Chomczynski, P. and N. Sacchi. 1987. Single-step method of RNA isolation by acid guanidinium thiocyanate-phenolchloroform extraction. Anal. Biochem. 162: 156-159.

Cserjesi, P., B. Lilly, L. Bryson, Y. Wang, D.A. Sassoon, and E.N. Olson. 1992. MHox: A mesodermally restricted homeodomain protein that binds an essential site in the muscle creatine kinase enhancer. Development 115: 1087-1101.

Cserjesi, P., B. Lilly, C. Hinkley, M. Perry, and E.N. Olson. 1994. Homeodomain protein MHox and MADS protein myocyte enhancer-binding factor- 2 converge on a common element in the muscle creatine kinase enhancer. I. Biol. Chem. 269: $16740-16745$.

Davidson, D.R., A. Crawley, R.E. Hill, and C. Tickle. 1991. Position-dependent expression of two related homeobox genes in developing vertebrate limbs. Nature 352: 429-431.

Davis, A.P. and M.R. Capecchi. 1994. Axial homeosis and appendicular skeleton defects in mice with a targeted disruption of hoxd-11. Development 120: 2187-2198.

Desplan, C., J. Theis, and P.H. O'Farrell. 1988. The sequence specificity of homeodomain-DNA interaction. Cell 54: 1081-1090.

Dollé, P., A. Dierich, M. LeMeur, T. Schimmang, B. Schuhbaur, P. Chambon, and D. Duboule. 1993. Disruption of the Hoxd13 gene induces localized heterochrony leading to mice with neotenic limbs. Cell 75: 431-441.

Erlbacher, A., E.H. Filvaroff, S.E. Gitelman, and R. Derynck. 1995. Toward a molecular understanding of skeletal development. Cell 80: 371-378.

Fan, C.-M. and M. Tessier-Lavigne. 1994. Patterning of mammalian somites by surface ectoderm and notochord: Evidence for sclerotome induction by a hedgehog homolog. Cell 79: 1175-1186.

Favier, B., M. Le Meur, P. Chambon, and P. Dollé. 1995. Axial skeleton homeosis and forelimb malformations in Hoxd-11 mutant mice. Proc. Natl. Acad. Sci. 92: 310-314.

Gendron-Maguire, M., M. Mallo, M. Zhang, and T. Gridley. 1993. Hoxa-2 mutant mice exhibit homeotic transformation of skeletal elements derived from cranial neural crest. Cell 75: 1317-1331.

Grueneberg, D.A., S. Natesan, C. Alexandre, and M.Z. Gilman. 1992. Human and Drosophila homeodomain proteins that enhance the DNA-binding activity of serum response factor. Science 257: 1089-1095.

Hall, B.K. and T. Miyake. 1992. The membranous skeleton: the role of cell condensations in vertebrate skeletogenesis. Anat. Embryol. 186: 107-124.

Ham, A.W. 1987. Histology. J.B. Lippincott Company, Philadelphia, $\mathrm{Pa}$.

Hollenberg, S.M., P.F. Cheng, and H. Weintraub. 1993. Use of a conditional MyoD transcription factor in studies of MyoD trans-activation and muscle determination. Proc. Natl. Acad. Sci. 90: 8028-8032.

Izpisúa-Belmonte, J.-C. and D. Duboule. 1992. Homeobox genes and pattern formation in the vertebrate limb. Dev. Biol. 152: 
26-36.

Johnson, R.L., E. Laufer, R.D. Riddle, and C. Tabin. 1994. Ectopic expression of sonic hedgehog alters dorsal-ventral patterning of somites. Cell 79: 1165-1173.

Kern, M.J., D.P. Witte, M.D. Valerius, B.J. Aronow, and S.S. Potter. 1992. A novel murine homeobox gene isolated by a tissue specific PCR cloning strategy. Nucleic Acids Res. 20: 5189-5195.

Kuratani, S., J.F. Martin, S. Wawersik, B. Lilly, G. Eichele, and E.N. Olson. 1994. The expression pattern of the chick homeobox gene $g M H o x$ suggests a role in patterning of the limbs and face and in compartmentalization of somites. Dev. Biol. 161: 357-369.

Langille, R.M. 1994. Differentiation of craniofacial mesenchyme. In Differentiation and morphogenesis of bone led. B.K. Hall), pp. 1-63. CRC Press, Boca Raton, FL.

Laufer, E., C.E. Nelson, R.L. Johnson, B.A. Morgan, and C. Tabin. 1994. Sonic hedgehog and Fgf-4 act through a signaling cascade and feedback loop to integrate growth and patterning of the developing limb bud. Cell 79: 993-1003.

Le Douarin, N.M., C. Ziller, and G. Couly. 1993. Patterns of neural crest derivatives in the avian embryos: In vivo and in vitro studies. Dev. Biol. 159: 24-49.

Lumsden, A., N. Sprawson, and A. Graham. 1991. Segmental origin and migration of neural crest cells in the hindbrain region of the chick embryo. Development 113: 1281-1291.

Mansour, S.L., K.R. Thomas, and M.R. Capecchi. 1988. Disruption of the proto-oncogene int- 2 in mouse embryo-derived stem cells: A general strategy for targeting mutations to nonselectable genes. Nature 336: 348-352.

McMahon, A.P. and A. Bradley. 1990. The Wnt-1 (int-1) protooncogene is required for development of a large region of the mouse brain. Cell 62: 1073-1085.

Mitchell, P.J., P.M. Timmons, J.M. Hebert, P.W.J. Rigby, and R. Tjian. 1991. Transcription factor $A P-2$ is expressed in neural crest cell lineages during mouse embryogenesis. Genes Dev. 5: 105-119.

Moore, K.L. and T.V.N. Persaud, eds. 1993. The branchial or pharyngeal apparatus. In The developing human: Clinically oriented embryology, pp. 186-225. W.B. Saunders Company, Philadelphia, PA.

Morgan, B.A. and C. Tabin. 1994. Hox genes and growth: early and late roles in limb bud morphogenesis. In The evolution of developmental mechanisms (ed. M. Akam, P. Holland, P. Ingham, and G. Wrayl, pp. 181-186. The Company of Biologists Limited, Cambridge, UK.

Nichols, D.H. 1986. Formation and distribution of neural crest mesenchyme to the first pharyngeal arch region of the mouse embryo. Am. I. Anat. 176: 221-231.

Niswander, L., S. Jeffrey, G.R. Martin, and C. Tickle. 1994. A positive feedback loop coordinates growth and patterning in the vertebrate limb. Nature 371: 609-612.

Noden, D.M. 1983. The role of the neural crest in patterning of avial cranial skeletal, connective, and muscle tissues. Dev. Biol. 96: 144-165.

1988. Interactions and fates of avian craniofacial mesenchyme. Development (Suppl.) 103: 121-140.

Novacek, M.J. 1993. Patterns of diversity in the mammalian skull. In The skull (ed. J. Hankens and B.K Hall), Vol. 2, pp.438-545. The University of Chicago Press, Chicago, IL.

Opstelten, D.-J.E., R. Vogels, B. Robert, E. Kahlhoven, F. Zwartkruis, L. de Laaf, O.H. Destrée, K.A. Lawson, and F. Meijlink. 1991. The mouse homebox gene, $S 8$, is expressed during embryogenesis predominantly in mesenchyme. Mech. Dev. 34: $29-42$.

Ramirez-Solis, R., J. Rivera-Pérez, J.D. Wallace, M. Wims,
H. Zheng, and A. Bradley. 1992. Genomic DNA microextraction: A method to screen numerous samples. Anal. Biochem. 201: 331-335.

Rieppel, O. 1993. Patterns of diversity in the reptilian skull. In The skull, Vol. 2 (ed. J. Hanken and B.K. Hall), pp. 344-390. The University of Chicago Press, Chicago, IL.

Rijli, F.M., M. Mark, S. Lakkaraju, A. Dierich, P. Dollé, and P. Chambon. 1993. A homeotic transformation is generated in the rostral branchial region of the head by disruption of Hoxa-2, which acts as a selector gene. Cell 75: 1333-1349.

Robert, B., G.E. Lyons, B.K. Simandl, A. Kuroiwa, and M. Buckingham. 1991. The apical ectodermal ridge regulates Hox-7 and $H o x-8$ gene expression in developing chick limb buds. Genes \& Dev. 5: 2363-2374.

Satokata, I. and R. Maas. 1994. Msx1 deficient mice exhibit cleft palate and abnormalities of craniofacial and tooth development. Nature Genet. 6: 348-355.

Sechrist, J., G.N. Serbedzija, T. Scherson, S.E. Fraser, and M. Bronner-Fraser. 1993. Segmental migration of the hindbrain neural crest does not arise from its segmental generation. Development 118: 691-703.

Small, K.M. and S.S. Potter. 1993. Homeotic transformations and limb defects in Hox A11 mutant mice. Genes \& Dev. 7: 2318-2328

Takahashi, Y., M. Bontoux, and N.M. Le Douarin. 1991. Epithelio-mesenchymal interactions are critical for QUOX 7 expression and membrane bone differentiation in the neural crest derived from mandibular mesenchyme. EMBO I. 10: 2387-2393

Valarché, I., J.-P. Tissier-Seta, M.-R. Hirsch, S. Martinez, C. Goridis, and J.-F. Brunet. 1993. The mouse homeodomain protein Phox 2 regulates Ncam promoter activity in concert with Cux/CDP and is a putative determinant of neurotransmitter phenotype. Development 119: 881-896. 


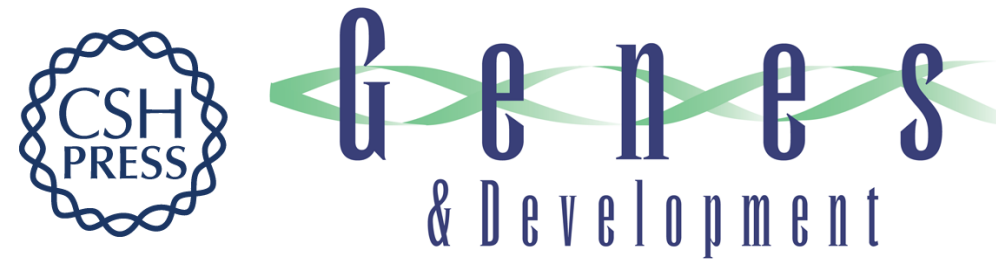

\section{The paired-like homeo box gene MHox is required for early events of skeletogenesis in multiple lineages.}

J F Martin, A Bradley and E N Olson

Genes Dev. 1995, 9:

Access the most recent version at doi:10.1101/gad.9.10.1237

References This article cites 37 articles, 13 of which can be accessed free at:

http://genesdev.cshlp.org/content/9/10/1237.full.html\#ref-list-1

License

Email Alerting

Service

Receive free email alerts when new articles cite this article - sign up in the box at the top right corner of the article or click here.

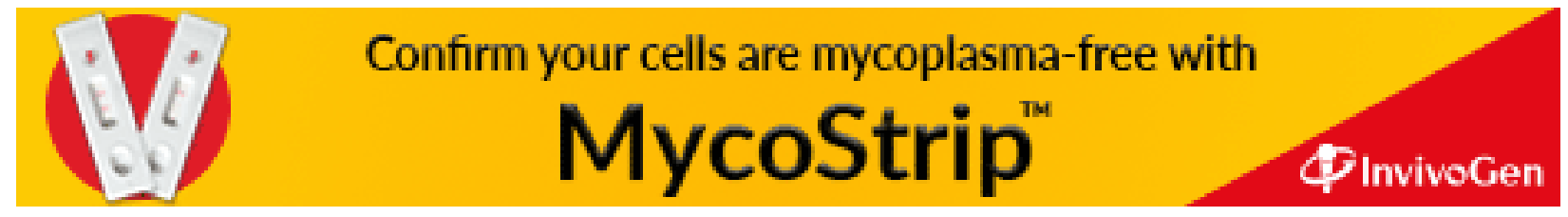

